' Kulkarni P, Hall RT, Rhodes P, Sheehan MB. Post-neonatal infant mortality in infants admitted to a neonatal intensive care unit. Pediatrics $1978 ; 62: 178-83$

2 Sills CJ, Neff TE, Bennett FC, Robinson NM. Mortality in infants discharged from a neonatal intensive care unit. Am $\mathcal{F}$ Dis Child 1983; 137:44-7.

${ }^{3}$ Harris JDC, Radford M, Wailoo MP, Carpenter RG, Machin D. Sudden infant death in Southampton and an evaluation of the Sheffield scoring system. F Epidemiol Community Health 1982;36:162-6.

(Accepted 24 October 1983)

Southampton General Hospital, Southampton SO9 4XY

JACKIE YARDLEY, SRN, HVCERT, research health visitor

MICHAEL P WAILOO, MD, MRCP, lecturer in child health

MARTIN HARMAN, BSC, MBCS, faculty computer programmer

Correspondence to: Dr M P Wailoo, department of child health.

\section{Incidence of cardiac arrhythmias in patients taking slow release salbutamol and slow release terbutaline for asthma}

The sustained release $\beta_{2}$ adrenergic agonists terbutaline and salbutamol are prescribed to prevent early morning attacks of asthma. We undertook a study to establish the incidence of cardiac arrhythmias caused by these drugs in a group of otherwise healthy patients with asthma.

\section{Patients, methods, and results}

Sixteen patients with asthma (11 men, five women; mean age 39 (range 19-60)) took part in a single blind crossover study lasting 14 days. None smoked or had clinically apparent cardiac disease. Treatment with cromoglycate (two patients) and steroid aerosols (seven) was allowed to continue during the study. One patient was taking a stable oral dose of steroids. All 16 patients were using a salbutamol aerosol before the study.

Patients underwent initial 12 hour Holter electrocardiography overnight and were then randomly allocated to receive either salbutamol sustained release tablets $8 \mathrm{mg}$ at night with a salbutamol metered dose inhaler $(100$ $\mu \mathrm{g} /$ dose) as required or terbutaline sustained release tablets $7.5 \mathrm{mg}$ twice daily with a terbutaline metered dose inhaler $(250 \mu \mathrm{g} / \mathrm{dose})$ as required. Each course of treatment lasted seven days, on the last night of which a 12 hour electrocardiogram was recorded. The patients were then changed to the other drug for the following week, on the last night of which a final 12 hour electrocardiogram was made. All electrocardiograms were analysed on a computerised system (Reynolds Pathfinder) by one of us (RH), who was unaware of which drug treatment (if any) each patient had received. The presence of any cardiac arrhythmia and the maximum heart rate attained during electrocardiography were noted. Patients were also provided with mini $W$ right peak flow meters and asked to record their peak expiratory flow rate daily on waking and going to bed.

The maximum heart rate during electrocardiography in the 16 patients increased from a baseline mean of 116 (SD 18) beats/min to 126 (19) after terbutaline and 122 (18) after salbutamol, but neither of these increases was significant. Five patients showed arrhythmias on one or more occasions (table). Three patients showed abnormalities on the electrocardiogram before receiving either drug. Five patients showed arrhythmias while receiving salbutamol and three while receiving terbutaline. Ventricular premature beats developed in the same three patients with both sustained release preparations, but the two patients with atrial extrasystoles on their baseline electrocardiograms developed paroxysmal atrial tachycardia only when receiving salbutamol. Palpitations did not occur during the two week study, although one patient had tremor.

\section{Comment}

Oral slow release $\beta_{2}$ adrenergic preparations have been reported to cause arrhythmias in patients with chronic obstructive airways disease, ${ }^{1}$ and the risks of these drugs in patients with ischaemic heart disease or a predisposition to it have been highlighted. Our study shows that arrhythmias may develop with or be exacerbated by both salbutamol and terbutaline in patients with asthma who are otherwise healthy.

There are several possible reasons for the increased incidence of arrhythmias other than the addition of the oral slow release $\beta_{2}$ agonists. Firstly, the patients' asthma may have deteriorated during treatment, leading to hypoxaemia; this may have been the case in two patients. Secondly, serum electrolyte concentrations, particularly potassium concentrations, may have altered. These were not measured as it is not our routine practice to do so before altering treatment with bronchodilators in outpatients. Thirdly, the use of methylxanthines may have had some effect but these were specifically stopped two weeks before the baseline electrocardiography and throughout the rest of the study.

The clinical importance of the cardiac arrhythmias is debatable. The risk of death in patients with coronary heart disease, is reportedly increased in the presence of frequent and complex ventricular premature beats on a six hour electrocardiogram, ${ }^{3}$ but none of our patients was known to have coronary heart disease. Further studies are therefore required to elucidate whether the arrhythmias observed with these $\beta_{2}$ agonists are caused or worsened by coexistant hypoxaemia or electrolyte imbalance and whether slow release methylxanthines or nebulised $\beta_{2}$ agonists cause fewer arrhythmias.

1 Pierson DJ, Hudson LD, Stark K, Hedgecock M. Cardiopulmonary effects of terbutaline and a bronchodilator combination in chronic obstructive pulmonary disease. Chest 1980;77:176-82.

2 Banner AS, Sunderratan EV, Agarwal MK, Addington WW. Arrhythmogenic effects of orally administered bronchodilators. Arch Intern Med $1979 ; 139: 434-7$.

${ }^{3}$ Hinkle LE. The frequency of asymptomatic disturbance of cardiac rhythm and conduction in middle-aged men. Am F Cardiol 1969;24:629-50.

(Accopted 13 October 1983)

\section{Middlesex Hospital, London W1N 8AA}

A H AL-HILLAWI, MB, MRCP, registrar, medical unit

R HAYWARD, MB, MRCP, senior registrar, department of cardiology

N M JOHNSON, MD, MRCP, senior lecturer, medical unit

Correspondence to: Dr A H Al-Hillawi, Brompton Hospital, London SW3 $6 \mathrm{HP}$.

Details of patients with asthma in whom arrhythmias were observed either before or during treatment with slow release $\beta_{2}$ agonist preparations

\begin{tabular}{|c|c|c|c|c|c|c|c|c|}
\hline \multirow{3}{*}{$\begin{array}{l}\text { Age } \\
\text { (years) }\end{array}$} & \multirow{3}{*}{ Sex } & \multirow{3}{*}{$\begin{array}{l}\text { Time of } \\
\text { assessment }\end{array}$} & \multirow{2}{*}{\multicolumn{2}{|c|}{ Baseline readings }} & \multicolumn{4}{|c|}{ Readings on seventh day of treatment } \\
\hline & & & & & \multicolumn{2}{|c|}{ Terbutaline } & \multicolumn{2}{|c|}{ Salbutamol } \\
\hline & & & $\begin{array}{l}\text { Maximum heart rate } \\
\text { (beats } / \mathrm{min} \text { ) }\end{array}$ & $\begin{array}{l}\text { Peak expiratory } \\
\text { flow rate }(1 / \mathrm{min})\end{array}$ & $\begin{array}{l}\text { Maximum heart rate } \\
\text { (beats/min) }\end{array}$ & $\begin{array}{l}\text { Peak expiratory } \\
\text { flow rate }(1 / \mathrm{min})\end{array}$ & $\begin{array}{l}\text { Maximum heart rate } \\
\text { (beats/min) }\end{array}$ & $\begin{array}{l}\text { Peak expiratory } \\
\text { flow rate }(1 / \mathrm{min})\end{array}$ \\
\hline 27 & $\mathrm{~F}$ & $\left\{\begin{array}{l}\text { Evening } \\
\text { Morning }\end{array}\right.$ & 132 & $\begin{array}{l}400 \\
250\end{array}$ & $\begin{array}{l}145 \\
\text { Bifocal ventricular } \\
\text { premature beats }\end{array}$ & $\begin{array}{l}\text { NA } \\
\text { NA }\end{array}$ & $\begin{array}{l}145 \\
\text { Single ventricular } \\
\text { premature beat }\end{array}$ & $\begin{array}{l}\text { NA } \\
\text { NA }\end{array}$ \\
\hline 42 & $M$ & $\left\{\begin{array}{l}\text { Evening } \\
\text { Morning }\end{array}\right.$ & $\begin{array}{l}\text { Single ventricular } \\
\text { premature beat }\end{array}$ & $\begin{array}{l}370 \\
350\end{array}$ & $\begin{array}{l}172 \\
\text { Single and paired } \\
\text { ventricular premature } \\
\text { beats }\end{array}$ & $\begin{array}{l}370 \\
340\end{array}$ & $\begin{array}{c}110 \\
\text { Single ventricular } \\
\text { premature beat }\end{array}$ & $\begin{array}{l}480 \\
410\end{array}$ \\
\hline 60 & $M$ & $\left\{\begin{array}{l}\text { Evening } \\
\text { Morning }\end{array}\right.$ & 135 & $\begin{array}{l}200 \\
150\end{array}$ & $\begin{array}{l}142 \\
\text { Frequent bifocal } \\
\text { ventricular premature } \\
\text { beats }\end{array}$ & $\begin{array}{l}100 \\
100\end{array}$ & $\begin{array}{l}115 \\
\text { Unifocal ventricular } \\
\text { premature beats }\end{array}$ & $\begin{array}{l}100 \\
100\end{array}$ \\
\hline 31 & $M$ & $\left\{\begin{array}{l}\text { Evening } \\
\text { Morning }\end{array}\right.$ & $\begin{array}{l}134 \\
\text { Atrial extrasystole }\end{array}$ & $\begin{array}{l}\text { NA } \\
\text { NA }\end{array}$ & 115 & $\begin{array}{l}\text { NA } \\
\text { NA }\end{array}$ & $\begin{array}{l}130 \\
\text { Salvos of atrial } \\
\text { tachycardia }\end{array}$ & $\begin{array}{l}\text { NA } \\
\text { NA }\end{array}$ \\
\hline 60 & $M$ & $\left\{\begin{array}{l}\text { Evening } \\
\text { Morning }\end{array}\right.$ & $\begin{array}{l}105 \\
\text { Atrial extrasystoles }\end{array}$ & $\begin{array}{l}370 \\
320\end{array}$ & 115 & $\begin{array}{l}280 \\
270\end{array}$ & $\begin{array}{l}150 \\
\text { Paroxysmal atrial } \\
\text { tachycardia }\end{array}$ & $\begin{array}{l}280 \\
200\end{array}$ \\
\hline
\end{tabular}

